\title{
HIPERTENSI DAN RETINOPATI HIPERTENSI
}

\author{
Alfa Sylvestris*
}

\begin{abstract}
ABSTRAK
Hipertensi merupakan masalah kesehatan global yang memerlukan penanggulangan yang baik. Terdapat beberapa faktor yang mempengarubi prevalensi hipertensi seperti ras, umur, obesitas, asupan garam yang tinggi, dan adanya riwayat hipertensi dalam keluarga. Prevalensi hipertensi di Indonesia 6-15\% pada orang dewasa, 50\% diantaranya tidak menyadari sebagai penderita hipertensi sehingga mereka cenderung untuk menjadi hipertensi berat karena tidak menghindari dan tidak mengetahui faktor risikonya.

Hipertensi menimbulkan akibat (komplikasi), baik jangka pendek maupun jangka panjang. Akibat jangka pendek disebabkan oleh kenaikan yang cepat dari tekanan darah sehingga terjadi kerusakan (nekrosis) pada dinding pembuluh darah. Akibat jangka panjang disebabkan oleh lamanya tekanan darah tinggi tersebut mempengarubi dinding pembuluh darah.

Peningkatan tekanan darah sistemik berbubungan dengan peningkatan tonus vaskular, di dalam mekanisme tersebut, terdapat penurunan produksi atau akivitas mediator vasodilatasi seperti endothelium-derived nitric oxide dan protasiklin, pada saat yang sama terdapat mekanisme peningkatan produksi mediator vasokonstriksi seperti angiotensin II dan endotelin-1. Ketidakseimbangan tersebut dinamakan disfungsi endotel.

Komplikasi hipertensi melibatkan beberapa organ vital tubuh seperti : penyakit jantung dan pembuluh darah, penyakit hipertensi serebrovaskular, hipertensi ensefalopati dan hipertensi retinopati. Pada keadaan hipertensi, pembuluh darah retina akan mengalami beberapa seri perubahan patofisiologis sebagai respon terhadap peningkatan tekanan darah. Terjadi spasme arterioles dan kerusakan endothelial pada tahap akut, pada tahap kronis terjadi hialinisasi pembulub darah yang menyebabkan berkurangnya elastisitas pembuluh darah. Hipertensi retinopati menunjukkan keparahan dan kronisitas dari bipertensi dan tanda-tanda retinopati ini dapat dipakai untuk memprediksi mortalitas pada pasien hipertensi.
\end{abstract}

Kata kunci : hipertensi - retinopati hipertensi - mortalitas pasien bipertensi

\footnotetext{
* Staff Pengajar di Fakultas Kedokteran

Universitas Muhammadiyah Malang
} 


\title{
HYPERTENSION AND RETINOPATHY HYPERTENSION
}

\section{Alfa Sylvestris*}

\begin{abstract}
Hipertension as a global problem need to be treated properly. Race, age, obesity, natrium intake, and familial history are foctors infuence prevalention of bypertension. There are $15 \%$ bypertension among adult people in Indonesia, which is $50 \%$ of them have no knowlage about their problem

Acute complication in bypertension increased of blood preassure leading in necrotic of vessel wall of chronic complication.

Increasing of systemic blood pressure has correlation with increase of vascular tonus. Decrease of production and activity of vasodilatation mediator such as endothelium-derived nitric oxide and prostacyclin happened with increase of production of vasoconstriction mediator such as angiotensin II and endothelin-1. This imbalance condition called endothelial dysfunction.

In acute bypertension, spasme of retinal arteriole happened with endothelial damage process. In chronic process, bialinisation retinal vessel leading in decreasing of vessel elasticity. Retinopathy of bypertension shows severity and chronicity in bypertension. The signs of retinopathy can be used to predicted the mortality in bypertension patients.
\end{abstract}

Key word : bypertension - retinopathy byonpertensi - mortality in bypertension patients.

\section{Definisi dan Klasifikasi Hipertensi}

Menurut The Joint National Committee on Prevention, Detection, Evaluation, and Treatment of High Blood Pressure (JNC) hipertensi adalah suatu sindrom atau kumpulan gejala kardiovaskuler yang progresif, sebagai akibat dari kondisi lain yang kompleks dan saling berhubungan. Berdasarkan penyebabnya, hipertensi dibagi menjadi 2 golongan yaitu hipertensi primer yang tidak diketahui sebabnya atau idiopatik dan hipertensi sekunder yaitu hipertensi yang disebabkan oleh penyakit lain. (Susalit, 2001)

Untuk menilai apakah seseorang itu menderita penyakit hipertensi atau tidak haruslah ada suatu standar nilai ukur dari tekanan darah. Berbagai macam klasifikasi hipertensi digunakan di masing-masing negara seperti klasifikasi menurut The Seventh Report of The Joint National Committee on Prevention, Detection, Evaluation, and Treatment of High Blood Pressure (JNC VII) yang digunakan di negara Amerika Serikat, klasifikasi menurut Chinese Hypertension Society yang digunakan di China, klasifikasi menurut European Society of Hypertension (ESH) yang digunakan negara-negara di eropa, klasifikasi menurut International Society on Hypertension in Blacks (ISHIB) yang khusus digunakan untuk warga keturunan Afrika yang tinggal di Amerika. Klasifikasi hipertensi menurut JNC VII terbagi menjadi kelompok normal, prahipertensi, hipertensi derajat 1 dan derajat 2. (Yogiantoro, 2006)

Tabel 1. Klasifikasi hipertensi menurut JNC VII (2003):

\begin{tabular}{|l|c|c|c|}
\hline Tekanan darah & Sistolik & & Diastolik \\
\hline Normal & $<120$ & Dan & $<80$ \\
\hline Pra-Hipertensi & $120-139$ & Atau & $80-89$ \\
\hline Hipertensi st. 1 & $140-159$ & Atau & $90-99$ \\
\hline Hipertensi st. 2 & $=160$ & Atau & $=100$ \\
\hline
\end{tabular}

(Sumber: The Seventh Report of The Joint National Committee on Prevention, Detection, Evaluation, and Treatment of High Blood Pressure, 2003) 


\section{Etiologi dan Faktor Resiko Hipertensi}

Risiko relatif hipertensi tergantung pada jumlah dan keparahan dari faktor risiko yang dapat dimodifikasi dan yang tidak dapat dimodifikasi. Faktor-faktor yang tidak dapat dimodifikasi antara lain faktor genetik, umur, jenis kelamin, dan etnis. Sedangkan faktor yang dapat dimodifikasi meliputi stres, obesitas dan nutrisi. (Anggraini, 2009)

Faktor-faktor yang mempengaruhi hipertensi yaitu:

Faktor Genetik

Adanya faktor genetik pada keluarga tertentu akan menyebabkan keluarga itu mempunyai resiko menderita hipertensi. Orang yang memiliki orang tua dengan riwayat hipertensi mempunyai resiko dua kali lebih besar untuk menderita hipertensi dari pada orang yang tidak mempunyai keluarga dengan riwayat hipertensi. (Soesanto, 2001)

\section{- Umur}

Peningkatan umur akan menyebabkan beberapa perubahan fisiologis. Pada usia lanjut terjadi peningkatan resistensi perifer dan aktivitas simpatik. Pengaturan tekanan darah yaitu refleks baroreseptor pada usia lanjut berkurang sensitivitasnya, peran ginjal juga berkurang dimana aliran darah ginjal dan laju filtrasi glomerulus menurun sehingga ginjal akan menahan garam dan air dalam tubuh. (Anggraini, 2009)

\section{- Jenis Kelamin}

Laki-laki mempunyai resiko lebih tinggi untuk menderita hipertensi pada usia muda. Laki-laki juga mempunyai resiko lebih besar terhadap morbiditas dan mortalitas kardiovaskuler. Sedangkan di atas umur 50 tahun hipertensi lebih banyak terjadi pada wanita. (Wade, 2002)

- Ras

Hipertensi lebih banyak terjadi pada orang berkulit hitam dari pada yang berkulit putih. Sampai saat ini, belum diketahui secara pasti penyebabnya. (Anggraini, 2009)

\section{- Obesitas}

Menurut Hall (1994) perubahan fisiologis dapat menjelaskan hubungan antara kelebihan berat badan dengan tekanan darah, yaitu terjadinya resistensi insulin dan hiperinsulinemia, aktivasi saraf simpatis dan sistem renin-angiotensin, dan perubahan fisik pada ginjal. Peningkatan konsumsi energi juga meningkatkan insulin plasma, dimana natriuretik potensial menyebabkan terjadinya reabsorpsi natrium dan peningkatan tekanan darah secara terus menerus. (Anggraini, 2009)

\section{- Nutrisi}

Garam merupakan faktor yang sangat penting dalam patogenesis hipertensi. Hipertensi hampir tidak pernah ditemukan pada suku bangsa dengan asupan garam yang minimal. (Susalit, 2001)

\section{Kebiasaan Merokok}

Perokok berat dapat dihubungkan dengan peningkatan insiden hipertensi maligna dan risiko terjadinya stenosis arteri renal yang mengalami ateriosklerosis. (Anggraini, 2009)

\section{Patofisiologi Hipertensi}

Patofisiologi terjadinya hipertensi adalah melalui terbentuknya angiotensin II dari angiotensin I oleh angiotensin I converting ensyme (ACE). ACE memegang peran fisiologis penting dalam mengatur tekanan darah. Darah mengandung angiotensinogen yang diproduksi di hati. Selanjutnya oleh hormon renin akan diubah menjadi angiotensin I. Oleh $A C E$ yang terdapat di paru-paru, angiotensin I diubah menjadi angiotensin II. (Anggraini, 2009)

Renin disintesis dan disimpan dalam bentuk inaktif yang disebut prorenin dalam sel-sel jukstaglomerular (sel JG) pada ginjal. Sel JG merupakan modifikasi dari sel-sel otot polos yang terletak pada dinding arteriol aferen tepat di proksimal glomeruli. Bila tekanan arteri menurun, reaksi intrinsik dalam ginjal itu sendiri menyebabkan banyak molekul protein dalam sel JG terurai dan melepaskan renin.

Angiotensin II adalah vasokonstriktor yang sangat kuat dan memiliki efek-efek lain yang juga mempengaruhi sirkulasi. Selama angiotensin II ada dalam darah, maka angiotensin II mempunyai dua pengaruh utama yang dapat meningkatkan tekanan arteri. Pengaruh pertama, yaitu vasokonstriksi, timbul dengan cepat. Vasokonstriksi terjadi terutama pada arteriol dan sedikit lemah pada vena. Cara kedua dimana angiotensin II meningkatkan tekanan arteri adalah dengan bekerja pada ginjal untuk menurunkan ekskresi garam dan air.

Vasopresin, disebut juga antidiuretic hormone $(A D H)$, bahkan lebih kuat daripada angiotensin sebagai vasokonstriktor, jadi kemungkinan merupakan bahan vasokonstriktor yang paling kuat dari ubuh. Bahan ini dibentuk di hipotalamus tetapi diangkut menuruni pusat akson saraf ke glandula 
hipofise posterior, dimana akhirnya disekresi ke dalam darah.

Aldosteron, yang disekresikan oleh sel-sel zona glomerulosa pada korteks adrenal, adalah suatu regulator penting bagi reabsorpsi natrium $\left(\mathrm{Na}^{+}\right)$dan sekresi kalium $\left(\mathrm{K}^{+}\right)$oleh tubulus ginjal. Tempat kerja utama aldosteron adalah pada sel-sel prinsipal di tubulus koligentes kortikalis. Mekanisme dimana aldosteron meningkatkan reabsorbsi natrium sementara pada saat yang sama meningkatkan sekresi kalium adalah dengan merangsang pompa natriumkalium ATPase pada sisi basolateral dari membran tubulus koligentes kortikalis. Aldosteron juga meningkatkan permeabilitas natrium pada sisi luminal membran. (Guyton, 1997)

Sampai sekarang pengetahuan tentang patogenesis hipertensi primer terus berkembang karena belum didapat jawaban yang memuaskan yang dapat menerangkan terjadinya peninkatan tekanan darah. Tekanan darah dipengaruhi oleh curah jantung dan tahanan perifer. (Susalit, 2001)

\section{Komplikasi Hipertensi}

Komplikasi karena hipertensi dapat mengenai berbagai organ vital tubuh, seperti : penyakit jantung dan pembuluh darah, penyakit hipertensi serebrovaskular, hipertensi ensefalopati dan hipertensi retinopati. (Gumanti, 1999)

1. Penyakit jantung dan pembuluh darah

Hipertensi merupakan penyebab paling umum dari hipertrofi ventrikel kiri. Dua bentuk utama penyakit jantung yang timbul pada penderita hipertensi yaitu penyakit jantung koroner dan penyakit jantung hipertensi.

\section{Penyakit hipertensi serebrovaskular}

Hipertensi adalah faktor resiko paling penting untuk timbulnya stroke pendarahan atau ateroemboli. Pendarahan kecil atau penyumbatan dari pembuluh-pembuluh kecil dapat menyebabkan infark pada daerah-daerah kecil. 3. Ensefalopati hipertensi

Ensefalopati hipertensi yaitu sindroma yang ditandai dengan perubahan-perubahan neurologis mendadak atau sub akut yang timbul akibat tekanan arteri yang meningkat, dan kembali normal apabila tekanan darah diturunkan. Sindroma ini dapat timbul pada setiap macam hipertensi, tapi jarang pada aldosteronisme primer dan koarktasio aorta.
Ensefalopati hipertensi biasanya ditandai oleh sakit kepala hebat, bingung, sering muntah-muntah, mual dan gangguan penglihatan.

4. Kelainan pada mata

Hipertensi juga memiliki komplikasi pada mata yaitu:

a. Oklusi vena retina

Penyumbatan suplai darah dalam vena ke retina yang dapat terjadi karena pengerasan pembuluh darah dalam mata.

b. Oklusi arteri retina

Penyumbatan suplai darah dalam arteri ke retina. Arteri retina dapat tersumbat oleh gumpalan darah atau zat-zat (seperti lemak) yang terjebak dalam arteri. Sumbatan ini dapat terjadi karena pengerasan pembuluh darah di mata.

c. Makroaneurisma arteri retina

Makroaneurisma pada arteri retina yang merupakan gejala akibat tekanan daerah di sekitarnya.

d. Iskemik neuropati optik anterior

Defisiensi aliran darah pada bagian saraf optik anterior sehingga terjadi neuropati pada saraf tersebut.

e. Ocular motor nerve palsy

Kelumpuhan nervus okulomotor yang mengakibatkan gerakan bola mata terganggu.

f. Retinopati hipertensi. (Kanski, 2003)

\section{Retinopati Hipertensi}

Retina dan pembuluh darahnya mudah dipengaruhi hipertensi. Salah satu target organ hipertensi adalah mata. Hipertensi yang berlangsung lama pada penderita dapat mempercepat timbulnya sklerosis pembuluh darah halus. Perubahan dinding pembuluh darah halus retina yang mengeras disebut retinopati hipertensi. (Mitchell, 2004, Hughes, 2007)

Retinopati hipertensi adalah suatu kondisi dengan karakteristik perubahan vaskularisasi retina pada populasi yang menderita hipertensi. Kelainan ini pertama kali dikemukakan oleh Marcus Gunn pada kurun ke-19 pada sekelompok penderita hipertensi dan penyakit ginjal. Tanda-tanda pada retina yang diobservasi adalah penyempitan arteriolar secara general dan fokal, perlengketan atau nicking arteriovenosa, perdarahan retina dengan bentuk 
flame-shape dan blot-shape, cotton-wool spots, dan edema papilla. Pada tahun 1939, Keith et al menunjukkan bahwa tanda-tanda retinopati ini dapat dipakai untuk memprediksi mortalitas pada pasien hipertensi. (Mitchell, 2004, Hughes, 2007)

Retinopati hipertensi adalah retinopati yang berkaitan dengan hipertensi esensial atau maligna. Perubahan-perubahan yang terjadi dapat mencakup penyempitan arteriola retina yang tidak teratur, perdarahan pada lapisan serat saraf dan lapisan pleksiform luar, eksudat dan bercak cotton-wool, lipid star dalam makula, perubahan arteriosklerotik, dan pada hipertensi maligna, papiledema. Retinopati hipertensi dapat juga disebabkan karena hipertensi yang tidak terkontrol. Pada retinopati hipertensi, pemeriksaan funduskopi dapat menolong menilai prognosa dan juga beratnya tekanan darah tinggi. Penelitian belakangan ini menduga bahwa retinopati hipertensi stadium III dan IV berhubungan dengan prognosa jangka panjang yang jelek. Retinopati hipertensi stadium lanjut (III dan IV) ditemukan kurang dari 10\% dari semua penderita hipertensi dan merupakan indikasi untuk penelitian diagnostik dan pengobatan yang agresif. (Gumanti, 1999, Kanski, 2003)

\section{Klasifikasi Retinopati Hipertensi}

Tabel 2. Klasifikasi retinopati hipertensi berdasarkan Scheie (1953).

\begin{tabular}{|l|l|}
\hline Stadium & \multicolumn{1}{|c|}{ Karakteristik } \\
\hline Stadium 0 & Ada diagnosis hipertensi tanpa abnormalitas pada retina \\
\hline Stadium I & $\begin{array}{l}\text { Penyempitan arteriolar difus, tiada konstriksi fokal, pelebaran refleks arterioler } \\
\text { retina }\end{array}$ \\
\hline Stadium II & $\begin{array}{l}\text { Penyempitan arteriolar yang lebih jelas disertai konstriksi fokal, tanda } \\
\text { penyilangan arteriovenous }\end{array}$ \\
\hline Stadium III & Penyempitan fokal dan difus disertai hemoragik, copper-wire arteries \\
\hline Stadium IV & Edema retina, hard eksudat, papiledema, silver-wire arteries \\
\hline
\end{tabular}

(Sumber: Current concept bypertensive retinopathy. The New England Journal of Medicine, 2004)

Tabel 3. Modifikasi klasifikasi Scheie oleh American Academy of Ophtalmology.

\begin{tabular}{|c|l|}
\hline Stadium & \multicolumn{1}{|c|}{ Karakteristik } \\
\hline Stadium 0 & Tiada perubahan \\
\hline Stadium I & Penyempitan arteriolar yang hampir tidak terdeteksi \\
\hline Stadium II & Penyempitan yang jelas dengan kelainan fokal \\
\hline Stadium III & Stadium II + perdarahan retina dan/atau eksudat \\
\hline Stadium IV & Stadium III + papiledema \\
\hline
\end{tabular}

(Sumber: Current concept hypertensive retinopathy. The New England Journal of Medicine, 2004) 

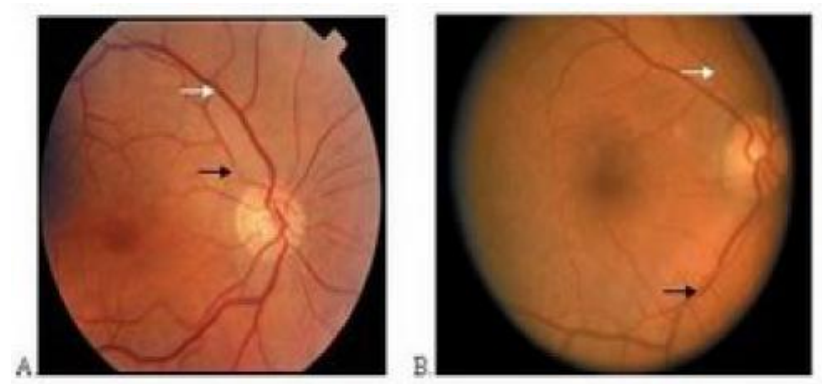

(Michell, 2004, McIntosh, 2005)

Gambar 1.

Mild Hypertensive Retinopathy. Nicking AV (panah putih) dan penyempitan focal arterioler (panah hitam) (A). Terlihat $A V$ nicking (panah hitam) dan gambaran copper wiring pada arterioles.
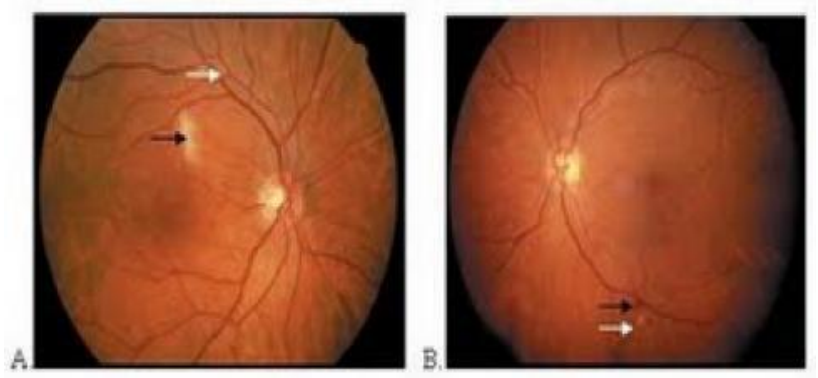

(Michell, 2004, McIntosh, 2005)

Gambar 2.

Moderate Hypertensive Retinopathy. AV nicking (panah putih) dan cotton wool spot (panah hitam)

(A). Perdarahan retina (panah hitam) dan gambaran cotton wool spot (panah putih) (B).

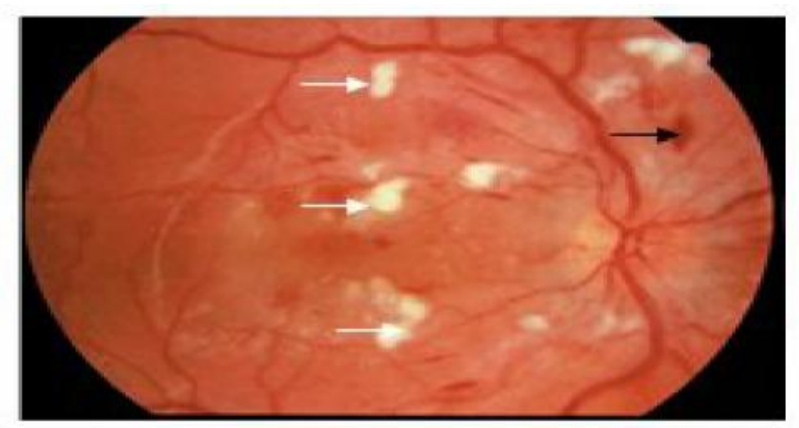

(Michell, 2004, McIntosh, 2005)

Gambar 4.

Severe Hypertensive Retinopathy Multiple cotton wool spot (panah putih) dan perdarahan retina (panah hitam) dan papiledema.

\section{Epidemiologi Retinopati Hipertensi}

Sejak tahun 1990 , sebanyak tujuh penelitian epidemiologis telah dilakukan pada sekelompok populasi penduduk yang menunjukkan gejala retinopati hipertensi. Berdasarkan grading dari gambaran funduskopi, menurut studi yang dijalankan didapatkan bahwa kelainan ini banyak ditemukan pada usia 40 tahun ke atas, walau pada mereka yang tidak pernah mempunyai riwayat hipertensi. Kadar prevalensi bervariasi antar 2\%-15\% untuk banyak macam tanda-tanda retinopati. Data ini berbeda dengan hasil studi epidemiologi yang dilakukan oleh Framingham Eye Study yang mendapatkan hasil prevalensi rata-rata kurang dari 1\%. Ini mungkin disebabkan oleh sensitivitas alat yang semakin baik apabila dibandingkan dengan pemeriksaan oftalmoskopik di klinik-klinik. Prevalensi yang lebih tinggi juga ditemukan pada orang berkulit hitam berbanding orang kulit putih berdasarkan insiden kejadian hipertensi yang lebih banyak ditemukan pada orang berkulit hitam. Akan tetapi, tidak ada predileksi rasial yang pernah dilaporkan berkaitan kelainan ini hanya saja pernah dilaporkan bahwa hipertensi lebih banyak ditemukan pada orang Kaukasian berbanding orang Amerika Utara. (Mitchell, 2004)

\section{Patofisiologi Retinopati hipertensi}

Pada keadaan hipertensi, pembuluh darah retina akan mengalami beberapa seri perubahan patofisiologis sebagai respon terhadap peningkatan tekanan darah. Terdapat teori bahwa terjadi spasme arterioles dan kerusakan endothelial pada tahap akut sementara pada tahap kronis terjadi hialinisasi pembuluh darah yang menyebabkan berkurangnya elastisitas pembuluh darah.

Pada tahap awal, pembuluh darah retina akan mengalami vasokonstriksi secara generalisata. Ini merupakan akibat dari peningkatan tonus arteriolus dari mekanisme autoregulasi yang seharusnya berperan sebagai fungsi proteksi. Pada pemeriksaan funduskopi akan kelihatan penyempitan arterioles retina secara generalisata. Peningkatan tekanan darah secara persisten akan menyebabkan terjadinya penebalan intima pembuluh darah, hiperplasia dinding tunika media dan degenerasi hyalin. Pada tahap ini akan terjadi penyempitan arteriolar yang lebih berat dan perubahan pada persilangan arteri-vena yang dikenal sebagai arteriovenous nicking. Terjadi juga perubahan 
pada refleks cahaya arteriolar yaitu terjadi pelebaran dan aksentuasi dari refleks cahaya sentral yang dikenal sebagai copper wiring. (Mitchell, 2004)

Selanjutnya akan terjadi tahap pembentukan eksudat, yang akan menimbulkan kerusakan pada sawar darah-retina, nekrosis otot polos dan sel-sel endotel, eksudasi darah dan lipid, dan iskemik retina. Perubahan-perubahan ini bermanifestasi pada retina sebagai gambaran mikroaneurisma, hemoragik, hard exudate dan infark pada lapisan serat saraf yang dikenal sebagai cotton-wool spot. Edema diskus optikus dapat terlihat pada tahap ini, dan biasanya merupakan indikasi telah terjadi peningkatan tekanan darah yang sangat berat. (Hughes, 2007)

\section{Diagnosa Retinopati Hipertensi}

Diagnosa retinopati hipertensi ditegakkan berdasarkan anamnesis dan pemeriksaan fisis. Selain itu pemeriksaan penunjang seperti funduskopi, pemeriksaan visus, pemeriksaan tonometri terutama pada pasien lanjut usia dan pemeriksaan USG BScan untuk melihat kondisi di belakang lensa diperlukan untuk membantu menegakkan diagnosis pasti. Pemeriksaan laboratorium juga penting untuk menyingkirkan penyebab lain retinopati selain dari hipertensi.

Pasien dengan hipertensi biasanya akan mengeluhkan sakit kepala dan nyeri pada mata. Penurunan penglihatan atau penglihatan kabur hanya terjadi pada stadium III atau stadium IV peubahan vaskularisasi akibat hipertensi. Arteriosklerosis tidak memberikan simptom pada mata. Hipertensi dan perubahan arteriosklerosis pada fundus diketahui melalui pemeriksaan funduskopi, dengan pupil dalam keadaan dilatasi. Biasa didapatkan perubahan pada vaskularisasi retina, infark koroid tetapi kondisi ini jarang ditemukan pada hipertensi akut yang memberikan gambaran Elschnig's spot yaitu atrofi sirkumskripta dan dan proloferasi epitel pigmen pada tempat yang terkena infark. Pada bentuk yang ringan, hipertensi akan meyebabkan peningkatan reflek arteriolar yang akan terlihat sebagai gambaran copper wire atau silver wire.

Penebalan lapisan adventisia vaskuler akan menekan venule yang berjalan dibawah arterioler sehingga terjadi perlengketan atau nicking arteriovenousa. Pada bentuk yang lebih ekstrem, kompresi ini dapat menimbulkan oklusi cabang vena retina (Branch Retinal Vein Occlusion/ BRVO). Dengan level tekanan darah yang lebih tinggi dapat terlihat perdarahan intraretinal dalam bentuk flame shape yang mengindikasikan bahwa perdarahannya berada dalam lapisan serat saraf, CWS dan/ atau edema retina. Malignant hipertensi mempunya ciriciri papiledema dan dengan perjalanan waktu akan terlihat gambaran makula berbentuk bintang.

Lesi pada ekstravaskuler retina dapat terlihat sebagai gambaran mikroaneurisme yang diperkirakan akan terjadi pada area dinding kapiler yang paling lemah. Gambaran ini paling jelas terlihat melalui pemeriksaan dengan angiografi. Keadaan stasis kapiler dapat menyebabkan anoksia dan berkurangnya suplai nutrisi, sehingga menimbulkan formasi mikroanuerisma. Selain itu, perdarahan retina dapat terlihat. Ini akibat hilang atau berkurangnya integritas endotel sehingga terjadi ekstravasasi ke plasma, hingga terjadi perdarahan. Bercak-bercak perdarahan kelihatan berada di lapisan serat saraf kelihatan lebih jelas dibandingkan dengan perdarahan yang terletak jauh dilapisan fleksiform luar.

Edema retina dan makula diperkirakan terjadi melalui 2 mekanisme. Hayreh membuat postulat bahwa edema retina timbul akibat transudasi cairan koroid yang masuk ke retina setelah runtuhnya struktur RPE. Namun selama ini peneliti lain percaya bahwa cairan edematosa muncul akibat kegagalan autoregulasi, sehingga meningkatkan tekanan transmural pada arterioles distal dan kapiler proksimal dengan transudasi cairan ke dalam jeringan retina. Absorpsi komponen plasma dari cairan edema retina akan menyebabkan terjadinya akumulasi protein. Secara histologis, yang terlihat adalah residu edema dan makrofag yang mengandung lipid. Walaupun deposit lipid ini ada dalam berbagai bentuk dan terdapat dimana-mana di dalam retina, gambaran macular star merupakan bentuk yang paling dominan. Gambaran seperti ini muncul akibat orientasi lapisan Henle dari serat saraf yang berbentuk radier. (Hughes, 2007, RiodanEva, 1996, McIntosh, 2005)

Pemeriksaan laboratorium harus mencantumkan permintaan untuk pengukuran tekanan darah, urinalisis, pemeriksaan darah lengkap terutama kadar hematokrit, kadar gula darah, pemeriksaan elektrolit darah terutama kalium dan kalsium, fungsi ginjal terutama kreatinin, profil lipid dan kadar asam urat. Selain itu pemeriksaan foto 
yang dapat dianjurkan termasuk angiografi fluorescein dan foto toraks. Pemeriksaan lain yang mungkin bermanfaat dapat berupa pemeriksaan elektrokardiogram. (Hughes, 2007)

\section{Penatalaksanaan Retinopati Hipertensi}

Mengobati faktor primer adalah sangat penting jika ditemukan perubahan pada fundus akibat retinopati arterial. Tekanan darah harus diturunkan dibawah 140/90 mmHg. Jika telah terjadi perubahan pada fundus akibat arteriosklerosis, maka kondisi ini tidak dapat diobati lagi. Beberapa studi eksperimental dan percobaan klinik menunjukan bahwa tanda-tanda retinopati hipertensi dapat berkurang dengan mengontrol kadar tekanan darah. Masih tidak jelas apakah pengobatan dengan obat anti hipertensi mempunyai efek langsung terhadap struktur mikrovaskuler. Penggunaan obat ACE Inbibitor terbukti dapat mengurangi kekeruhan dinding arteri retina sementara penggunaan HCT tidak memberikan efek apa pun terhadap pembuluh darah retina. Perubahan pola dan gaya hidup juga harus dilakukan. Pasien dinasehati untuk menurunkan berat badan jika sudah melewati standar berat badan ideal seharusnya. Konsumsi makanan dengan kadar lemak jenuh harus dikurangi sementara intake lemak tak jenuh dapat menurunkan tekanan darah. Konsumsi alkohol dan garam perlu dibatasi dan pasien memerlukan kegiatan olahraga yang teratur. (Hughes, 2007, Lang, 2000)

Dokter atau petugas kesehatan harus tetap meneruskan pengobatan pada pasien hipertensi walaupun tanpa tanda-tanda retinopati. Evaluasi dan manajemen pada pasien dengan hipertensi harus diutamakan supaya tidak terjadi komplikasi ke target organ yang lain. Terapi terkini untuk retinopati hipertensi dengan perdarahan intraretinal adalah laser fotokoagulasi. (Hughes, 2007, McIntosh, 2005)

\section{DAFTAR PUSTAKA}

Anggraini, Ade Dian dkk, 2009, Faktor-faktor yang Berbubungan dengan kejadian Hipertensi pada pasien yang Berobat di poliklinik dewasa Puskesmas bangkinang Periode januari sampai juni 2008, Fakultas Kedokteran Universitas Riau, Hal : BAB I, BAB II, http://yayanakhyar.files. wordpress.com, diakses 13 Maret 2010.

Gumanti, Tagor, 1999, Hipertensi Esensial, Buku Ajar Kardiologi, Balai Penerbit FKUI, Jakarta.

Guyton dan Hall, 1997, Fisiologi Kedokteran, Edisi 9, Terjemahan oleh Irawati Setiawan, EGC, Jakarta.

Hughes BM, Moinfar N, Pakainis VA, Law SK, Charles S, Brown LL et al, editor, Hypertension, http://www.emedicine.com/ oph/topic488.htm, diakses 15 Januari 2010.

Lang GK, dalam: Ophtalmology a short textbook: retina, edisi 1, New York, Thieme Stuttgart Germany; 2000, Hal: 299-314, 323-5

McIntosh R, Hypertensive retinopathy signs as risk indicators of cardiovascular morbidity and mortality, British Medical Bulletin 2005;73 and 74;57-70, http:// bmb.oxforsjournals.org/cgi/reprint/73-74/ 1/57, diakses 15 Januari 2010.

Mitchell P, Current concept hypertensive retinopathy, The New England Journal of Medicine 2004, (2004 November 25) 351:2310-7, http://www.neim.org/cgi/reprint/351/22/ 2310.pdf, diakses 4 Februari 2010.

Riodan-Eva P. In: Vaughan DG, Asbury T, RiodanEva P, editors. Oftalmologi umum: anatomi dan embriologi mata. 14th ed. Jakarta. Penerbit Widya Merdeka; 1996. p. 7-9

Soesanto, A. M. dkk, 2001, Reaktivitas Kardiovaskuler Individu Normotensi Dari Orang Tua Hipertensi Primer, Jurnal Kardiologi Indonesia, XXV (4) hal: 166 - 167.

Susalit E. Dkk, 2001, Buku Ajar Ilmu Penyakit Dalam Jilid II, Edisi III, Balai Penerbit FKUI, Jakarta.

The Seventh Report of The Joint National Committee on Prevention, Detection, Evaluation, and Treatment of High Blood Pressure (JNC VII), 2003, Prevention, Detection, Evaluation, and Treatment of High Blood Pressure, pp. 8-12, http:// nhlbi.nih.gov, diakses 21 Januari 2010. 
Wade, A Hwheir, D N Cameron, A, 2003, Using a Problem Detection Study (PDS) to Identify and Compare Health Care Privider and Consumer Views of Antibypertensive therapy, Journal of Human Hypertension, Jun Vol 17 Issue 6, p397

Yogiantoro, Mohammad, 2006, Hipertensi Primer, In : Sudoyo A, Setiyohadi B, Buku Ajar Ilmu Penyakit Dalam Jilid I, Edisi IV, Pusat Penerbitan FKUI, Jakarta, Hal : 610-614. 